4. Bait-Merabet L, Thille A, Legrand P, Brun-Buisson C, Cattoir V. Brachyspira pilosicoli bloodstream infections: case report and review of the literature. Ann Clin Microbiol Antimicrob. 2008;7:19.

5. Brooke CJ, Hampson DJ, Riley TV. In vitro antimicrobial susceptibility of Brachyspira pilosicoli isolates from humans. Antimicrob Agents Chemother. 2003;47:2354-7.

6. Helbling R, Osterheld MC, Vaudaux B, Jaton K, Nydegger A. Intestinal spirochetosis mimicking inflammatory bowel disease in children. BMC Pediatr. 2012;12:163.

7. Alsaigh N, Fogt F. Intestinal spirochetosis: clinicopathological features with review of the literature. Colorectal Dis. 2002;4:97-100.

8.. Marthinsen L, Willen R, Carlen B, Lindberg E, Varendh G. Intestinal spirochetosis in eight pediatric patients from Southern Sweden. APMIS. 2002;110:571-9.

\section{Immunoproliferative small intestinal disease: a report of 6 cases}

\section{Introduction}

Immunoproliferative small intestinal disease (IPSID) is a rare low-grade B-cell lymphoma arising from mucosa associated lymphoid tissue (MALT), representing approximately one-third of intestinal lymphoma. Histopathologically it is characterized by infiltration of small bowel wall with lymphocytes and plasma cells. The infiltrates produces an aberrant immunoglobulin (IgA), a truncated alpha heavy chain without the light chain component. ${ }^{1,2}$ Galian et $\mathrm{al}^{3}$ described the disease in three stages depending upon type of cellular infiltrate and mesenteric nodal involvement (Table 1). Presentation may mimic that of celiac disease, tropical sprue or parasitic infestation and patients are being treated on the line of celiac disease and other causes of malabsorption for prolonged duration before being diagnosed as IPSID/NHL. ${ }^{4,5}$ Emaciation and diarrhoea is due to malabsorption syndrome and protein losing enteropathy secondary to lymphoma infiltration of intestine. Most patients present during early stages and are curable with oral antimicrobials. ${ }^{6}$ Few may progress to high-grade lymphoma requiring systemic chemotherapy. We present here the clinico-
Table 1: The Galian staging system ${ }^{3}$

\begin{tabular}{lll}
\hline Stage & Small intestine & Lymph nodes \\
\hline A & $\begin{array}{l}\text { Lymphoplasmacytic or } \\
\text { plasmacytic infiltration of } \\
\text { the lamina propria, variable } \\
\text { villous atrophy }\end{array}$ & $\begin{array}{l}\text { Plasmacytic infiltration, } \\
\text { nodal architecture } \\
\text { generally preserved }\end{array}$ \\
B & $\begin{array}{l}\text { Atypical lymphoplasmacytes } \\
\text { or plasmacytes with }\end{array}$ & $\begin{array}{l}\text { Atypical plasmacytic } \\
\text { infiltrate with }\end{array}$ \\
& $\begin{array}{l}\text { immunoblast-like cells with } \\
\text { extension to at least } \\
\text { submucosa, subtotal or total } \\
\text { villous atrophy }\end{array}$ & $\begin{array}{l}\text { subtotal or total } \\
\text { effacement of nodal } \\
\text { architecture }\end{array}$ \\
& $\begin{array}{l}\text { Frankly malignant invasion } \\
\text { through entire intestinal wall }\end{array}$ & $\begin{array}{l}\text { Malignant effacement of } \\
\text { entire lymph node }\end{array}$ \\
\hline
\end{tabular}

pathological characteristics, treatment and outcome of six patients treated at our institute during the last 10 years, along with a review of literature.

\section{Case reports}

A total of six patients with median age of 27 years (range: 15$35)$ were identified and treated. Median duration of symptom was 13.5 months (range: 6-26). All patients presented with history of recurrent watery loose motion with decreased appetite, weight loss and low grade fever. The median time from diagnosis of malabsorption to diagnosis of IPSID was 10 months (range: 1-20). Test for alpha heavy chain protein (AHCP) in serum was not done.

Barium meal follow through showed ileo-ileal intussusception in case number 4 and 6 (Table 2). All patients showed evidence of oedematous mucosal thickening in small bowel and enlarged mesenteric lymph nodes on CT scan. Endoscopic biopsy of mucosal lesions showed diffuse infiltrate of small atypical lymphoid cells or lymphoplasmacytic cells (Figure 1A) which were $\mathrm{CD} 20^{+} \mathrm{CD} 3^{-}$with partial or total villous atrophy. Repeat biopsy during progression showed features of high grade B-cell lymphoma in case number 3 (Figures 1B \& 1C).

Galian stage, treatment details and outcome are summarised in Table 3. Case number 1 received 6 cycles of CHOP (cyclophosphamide, doxorubicin, vincristine, and prednisolone) and achieved complete response (CR) lasting for 10 months and then was lost to follow-up. Case 2 also received 6 cycles of CHOP with tetracycline (1g/day) and was in stable condition for 1 year after which the disease progressed, and the patient succumbed 45 months after initial 
Table 2: Radiology and histopathology features

\begin{tabular}{|c|c|c|c|c|c|c|}
\hline Inv estigation & Case 1 & Case 2 & Case 3 & Case 4 & Case 5 & Case 6 \\
\hline $\begin{array}{l}\text { Upper GI } \\
\text { endoscopy }\end{array}$ & $\begin{array}{l}\text { thick, } \\
\text { edematous folds } \\
\text { in stomach and } \\
\text { du odenum }\end{array}$ & $\begin{array}{l}\text { Nodular } \\
\text { infiltrated folds } \\
\text { in duodenum }\end{array}$ & $\begin{array}{l}\text { Nodular } \\
\text { mucosa in } \\
\text { entire } \\
\text { duodenum }\end{array}$ & $\begin{array}{l}\text { Edematous and } \\
\text { nodular mucosa in } \\
\text { duodenum }\end{array}$ & $\begin{array}{l}\text { Ulcerated, } \\
\text { edematous, } \\
\text { in filtrated mucosa } \\
\text { in duodenum with } \\
\text { a large polyp+ }\end{array}$ & $\begin{array}{l}\text { Edematous } \\
\text { mucosal folds in } \\
\text { duodenum }\end{array}$ \\
\hline Colonoscopy & Not done & Not done & Not done & $\begin{array}{l}\text { Edematous mucosa } \\
\text { with superficial } \\
\text { ulcers in whole } \\
\text { segment of colon }\end{array}$ & Normal & Not done \\
\hline $\begin{array}{l}\text { Site of } \\
\text { involvement }\end{array}$ & $\begin{array}{l}\text { Stomach, } \\
\text { du odenum and } \\
\text { jeju num }\end{array}$ & $\begin{array}{l}2^{\text {nd }} \text { part of } \\
\text { du odenum, } \\
\text { jeju num, ileum }\end{array}$ & $\begin{array}{l}\text { Duodenum, } \\
\text { jejunum, ileum }\end{array}$ & $\begin{array}{l}\text { Duod enum, ileum, } \\
\text { colon }\end{array}$ & $\begin{array}{l}\text { Duodenum, } \\
\text { jejunum, colon }\end{array}$ & Duodenum, ileum \\
\hline $\begin{array}{l}\text { Barium meal } \\
\text { follow-through }\end{array}$ & Not done & $\begin{array}{l}\text { Loss of mucosal } \\
\text { fold pattern in } \\
\text { du odenum and } \\
\text { thickening of } \\
\text { jejuna mucosal } \\
\text { folds }\end{array}$ & Normal & $\begin{array}{l}\text { Ileo-ileal } \\
\text { intussusceptions }\end{array}$ & Normal & $\begin{array}{l}\text { Ileo-ileal } \\
\text { in tu ssu sceptions }\end{array}$ \\
\hline CT scan & $\begin{array}{l}\text { Thickening of } \\
\text { small bowel } \\
\text { with dilatation, } \\
\text { multiple para- } \\
\text { aortic and } \\
\text { mesenteric } \\
\text { lymph nodes } \\
\text { enlarged }\end{array}$ & $\begin{array}{l}\text { Diffuse jejunal } \\
\text { wall thickening } \\
\text { with polypoidal } \\
\text { mass related to } \\
\text { ileum and } \\
\text { mesenteric } \\
\text { lymph node } \\
\text { enlargement }\end{array}$ & $\begin{array}{l}\text { Circumferentia } \\
1 \text { long segment } \\
\text { thickening of } \\
\text { distal jejunal } \\
\text { and ileal loops }\end{array}$ & $\begin{array}{l}\text { Long segment } \\
\text { mu cosal thickening } \\
\text { involving ileum } \\
\text { and colon with } \\
\text { ileo-ileal } \\
\text { intussusceptions } \\
\text { and mesenteric } \\
\text { lyp hadenopathy }\end{array}$ & $\begin{array}{l}\text { Non-specific } \\
\text { dilated bowel } \\
\text { loops with } \\
\text { mesenteric } \\
\text { lymphadenopathy }\end{array}$ & $\begin{array}{l}\text { Ileo-ileal } \\
\text { in tu ssu sception } \\
\text { with mesenteric } \\
\text { lymphaden opathy }\end{array}$ \\
\hline Systemic staging & Negative & Negative & Negative & Negative & Negative & Negative \\
\hline $\begin{array}{l}\text { Histopathology } \\
\text { (he matoxylin and } \\
\text { eosin) }\end{array}$ & $\begin{array}{l}\text { Diffuse } \\
\text { infiltration by } \\
\text { small lymphoid } \\
\text { cells }\end{array}$ & $\begin{array}{l}\text { Dense infiltrate } \\
\text { of lymphocyte } \\
\text { and plasma cells }\end{array}$ & $\begin{array}{l}\text { Diffuse } \\
\text { lymphop lasma } \\
\text { cytic in filtrate } \\
\text { in lamina } \\
\text { propria }\end{array}$ & $\begin{array}{l}\text { Lymphoplasmacyti } \\
\text { c infiltrate, focal } \\
\text { crypt arch itectural } \\
\text { distortion with } \\
\text { increased } \\
\text { intraepithelial } \\
\text { lymphocyte }\end{array}$ & $\begin{array}{l}\text { Diffu se cellular } \\
\text { in filtrate } \\
\text { comprising } \\
\text { mature B cells } \\
\text { admixed with } \\
\text { plasma cells and } \\
\text { occasional } \\
\text { lymphoepithelial } \\
\text { lesions with } \\
\text { villous atrophy }\end{array}$ & $\begin{array}{l}\text { Dense infiltration } \\
\text { of plasma cells } \\
\text { and few } \\
\text { mon onuclear } \\
\text { lymphoid cells in } \\
\text { lamin a propria } \\
\text { with villous } \\
\text { atrophy and } \\
\text { in traepithelial } \\
\text { lymphocytes }\end{array}$ \\
\hline Infiltrate & Small lympho id & $\begin{array}{l}\text { Lymphocyte } \\
\text { and plasma cells }\end{array}$ & $\begin{array}{l}\text { Lymphoplasma } \\
\text { cytic }\end{array}$ & $\begin{array}{l}\text { Lymphoplasmacyti } \\
\text { c }\end{array}$ & $\begin{array}{l}\text { Lymphocyte and } \\
\text { plasma cells }\end{array}$ & $\begin{array}{l}\text { Plasma cells and } \\
\text { lymphomo nonucl } \\
\text { ear cells }\end{array}$ \\
\hline Granuloma & No & No & No & No & No & No \\
\hline CD20 & $+v e$ & $+v e$ & $+\mathrm{ve}$ & Not done & $+\mathrm{ve}$ & Not done \\
\hline CD3 & - ve & - ve & - ve & Not done & -ve & -ve \\
\hline Ig stain & Not done & Kappa chain & Not done & Kappa chain & Not done & $\operatorname{Ig} \mathrm{A}$ \\
\hline
\end{tabular}

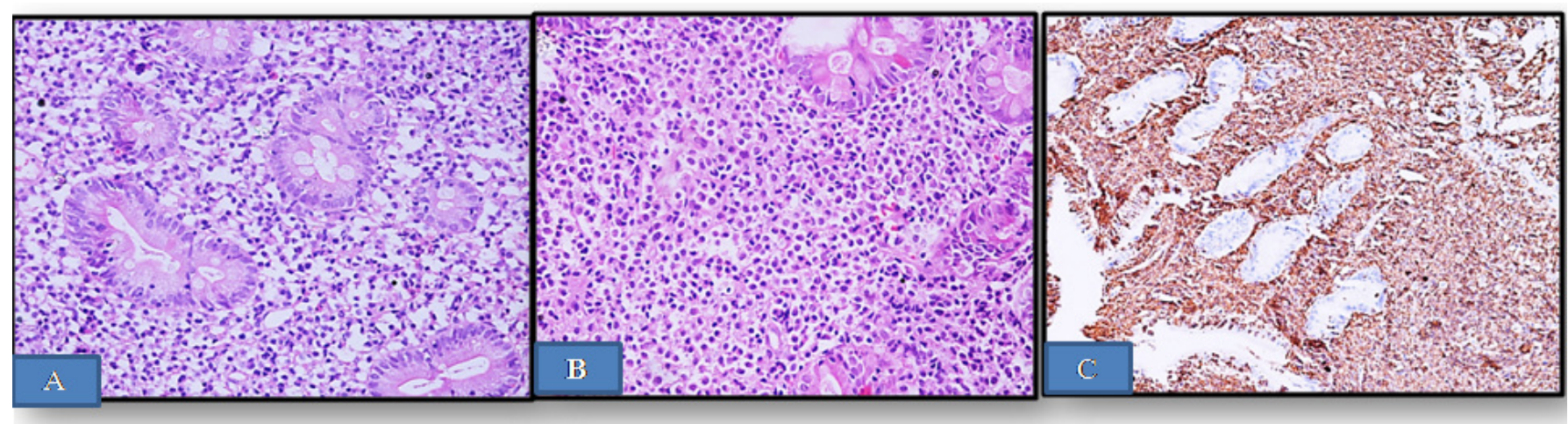

Figure 1: A) Jejunal biopsy showing dense lymphoplasmacytic infiltration of the lamina propria with normal epithelium. Some of the crypts show epithelial lymphocyte infiltration indicative of lymphoepithelial lesion (hematoxylin and eosin, x20); B) photomicrograph showing diffuse infiltration of large atypical lymphocytes in the lamina propria (hematoxylin and eosin, x20); C) the large atypical lymphocytes are CD20 positive, indicating a diffuse large B-cell lymphoma (IHC, DACO, x20). 
Table 3: Treatment and outcome

\begin{tabular}{|c|c|c|c|c|c|c|}
\hline Treatment parameters & Case 1 & Case 2 & Case 3 & Case 4 & Case 5 & Case 6 \\
\hline Galian stage & $\bar{A}$ & $\bar{A}$ & $\mathrm{~B}$ & $\mathrm{~A}$ & $\bar{A}$ & $\mathrm{~B}$ \\
\hline First-line therapy & $\mathrm{CHOP}$ & $\begin{array}{l}\mathrm{CHOP}+ \\
\text { an tibiotics }\end{array}$ & $\begin{array}{c}\mathrm{COP}+ \\
\text { an tibiotics }\end{array}$ & Antibiotics & Antibiotics & Antibiotics \\
\hline Antibiotics & Nil & Tetracycline & $\begin{array}{l}\text { Tetrac ycline }+ \\
\text { metronidazole }\end{array}$ & $\begin{array}{l}\text { Doxycycline + } \\
\text { metronidazole }\end{array}$ & Doxycycline & $\begin{array}{l}\text { Metronidazol } \\
\text { + doxycyclin }\end{array}$ \\
\hline $\begin{array}{l}\text { Duration of first-line } \\
\text { Therapy }\end{array}$ & 5 months & 1 year & 5 months & 7 months & 34 month s & 6 months \\
\hline $\begin{array}{l}\text { Respon se to first-line } \\
\text { therapy }\end{array}$ & $\begin{array}{l}\text { Complete } \\
\text { response }\end{array}$ & Stable disease & Stable disease & $\begin{array}{l}\text { Complete } \\
\text { response }\end{array}$ & $\begin{array}{l}\text { Partial } \\
\text { response }\end{array}$ & $\begin{array}{c}\text { Partial } \\
\text { response }\end{array}$ \\
\hline $\begin{array}{l}\text { Recurrence/ } \\
\text { progression }\end{array}$ & $\mathrm{Y}$ & $\mathrm{Y}$ & $\mathrm{Y}$ & $\mathrm{Y}$ & $\mathrm{N}$ & $\mathrm{N}$ \\
\hline $\begin{array}{l}\text { High-grade } \\
\text { transformation }\end{array}$ & $\mathrm{N}$ & $\mathrm{N}$ & $\mathrm{Y}$ & $\mathrm{N}$ & $\mathrm{N}$ & $\mathrm{N}$ \\
\hline Second-line treatmen $t$ & None & PEPC & $\mathrm{CHOP}$ & None & NA & NA \\
\hline $\begin{array}{l}\text { Respon se to second- } \\
\text { linetreatment }\end{array}$ & NA & $\begin{array}{c}\text { Progressive } \\
\text { disease }\end{array}$ & $\begin{array}{c}\text { Progressive } \\
\text { disease }\end{array}$ & NA & NA & NA \\
\hline Final outcome & $\begin{array}{l}\text { Lost to } \\
\text { follow-up }\end{array}$ & $\begin{array}{l}\text { Died in } \\
\text { progressive } \\
\text { disease }\end{array}$ & $\begin{array}{l}\text { Died in } \\
\text { progressive } \\
\text { disease }\end{array}$ & $\begin{array}{l}\text { Alive with } \\
\text { disease }\end{array}$ & $\begin{array}{l}\text { Alive with } \\
\text { disease }\end{array}$ & $\begin{array}{l}\text { A live with } \\
\text { disease }\end{array}$ \\
\hline $\begin{array}{l}\text { Progression-free } \\
\text { survival (months) }\end{array}$ & 10 & 37 & 6 & 18 & 64 & 8 \\
\hline $\begin{array}{l}\text { Overall survival } \\
\text { (months) }\end{array}$ & 17 & 45 & 120 & 22 & 64 & 8 \\
\hline
\end{tabular}

diagnosis of IPSID. Case 3 initially received CVP (cyclophosphamide, vincristine, and prednisolone) along with oral metronidazole and tetracycline (MT) without any response. Repeat biopsy revealed a high-grade B- non-Hodgkin's lymphoma (NHL). He was given 6 cycles of CHOP but his disease continued to progress. He eventually succumbed 120 months after diagnosis of IPSID. Case 4 achieved CR after MT lasting for 14 months. Currently she is asymptomatic and on regular follow-up. Case 5 achieved partial remission after oral doxycycline and is continuing on regular follow-up with same treatment. The last patient was diagnosed recently and is on doxycycline and metronidazole. Though the sample size is too small for survival analysis, we calculated a median progressionfree survival of 18 months and overall survival of 64 months after a median follow-up of 22 months.

\section{Discussion}

The infectious aetiology of IPSID has been supported by the demonstration of $\mathrm{H}$. pylori and $\mathrm{C}$. jejuni in tumor samples of IPSID. ${ }^{7,8} \mathrm{Al}$-Saleem et $\mathrm{al}^{9}$ reported the largest series comprising of 89 IPSID patients out of a total 145 cases of small intestinal lymphoma. There are few published reports from India as well. ${ }^{4,5,10}$ Presentation of our cases was similar to published literature; including chronic diarrhoea, abdominal pain, weight loss, low-grade fever and clubbing. ${ }^{9,11-13}$ Very few patients in literature with a diagnosis of chronic malabsorption syndrome have been reported as IPSID. ${ }^{14-16}$ The exact pathogenesis of IPSID is unknown. Pathologically it shows a spectrum of disease with alpha-HCD (with AHCP production), with Mediterranean lymphoma on one hand and frank high-grade malignant lymphoma on the other. AHCP is present in approximately $87 \%$ of patients with IPSID.${ }^{17}$ If left untreated the disease may progress to high-grade malignant lymphoma. Clinical staging depends on type of cellular infiltrate, severity of involvement and lymph node histopathology. Galian staging is most commonly used and classifies the disease into three stages (A, B and C).

The clinical course is indolent in IPSID. Though very responsive to antibiotics in early stages, the disease can progress to high-grade lymphoma if left untreated. It can cause severe morbidity secondary to malabsorption and protein losing enteropathy. Early treatment is important to control the disease and malabsorption and prevent its progression. ${ }^{13}$ In a retrospective study of 21 Tunisian patients with IPSID, 6 had early stage disease and responded well to antibiotics. 15 patients with high/intermediate grade disease were treated with an anthracycline containing combination chemotherapy 
(CHOP/or CHOP-like). The overall remission rate was $90 \pm 12 \%$ at 2 years and $67 \pm 25 \%$ at 3 years. ${ }^{18}$ In first 2 patients we employed anthracycline-based chemotherapy given our lack of experience. Another large Turkish study also reported similar results ${ }^{19}$ Rambaud et a ${ }^{13}$ recommended antibiotic treatment for early stage and CHOP for those with inadequate response to oral antibiotics and for advanced stage disease. The optimum duration for antibiotics is not known, and perhaps might be required lifelong. The role of surgery is limited and is used only for symptom palliation and rarely for salvage. The usual cause of death is disease progression or transformation to high-grade lymphoma and complications of malnutrition. In our study, all six patients showed early response to antibiotics but ultimately three patients suffered disease progression. Two patients died of progressive disease; one underwent transformation to high-grade B-cell lymphoma, while remaining three patients are doing well on treatment.

BIVAS BISWAS ${ }^{1}$

ATUL SHARMA ${ }^{1}$

GOVIND K MAKHARIA ${ }^{2}$ SANJAY THULKAR ${ }^{3}$ SUDHEER ARAVA ${ }^{4}$ ANKUR BAHL ${ }^{1}$ SURENDRA CHAUDHARY ${ }^{1}$

\section{Correspondence: Dr. Atul Sharma Departments of Medical Oncology $y^{l}$, Gastroenterology ${ }^{2}$, Radiodiagnosis ${ }^{3}$ and Pathology, ${ }^{4}$ Dr. B. R. A. Institute Rotary Cancer Hospital, All India Institute of Medical Sciences Ansari Nagar, New Delhi - 110029, India Email:atul1@hotmail.com}

\section{References}

1. Seligmann M, Danon F, Hurez D, Mihaesco E, Preud'homme JL. Alpha-chain disease: a new immunoglobulin abnormality. Science. 1968;162:1396-7.

2. Isaacson P, Wright DH. Malignant lymphoma of mucosaassociated lymphoid tissue. A distinctive type of B-cell lymphoma. Cancer. 1983;52:1410-6.

3. Galian A, Lecestre MJ, Scotto J, Bognel C, Matuchansky C, Rambaud JC. Pathological study of alpha-chain disease, with special emphasis on evolution. Cancer. 1977;39:2081-101.

4. Ghoshal UC, Chetri K, Banerjee PK, Choudhuri G, Pal BB, Dabadghao $\mathrm{S}$, et al. Is immunoproliferative small intestinal disease uncommon in India? Trop Gastroenterol. 2001;22:14-7.
5. Puri AS, Kumar M, Khan EM, Pandey R, Aggarwal R, Naik S, et al. Immunoproliferative small intestinal disease: a frequently missed diagnosis. Indian J Gastroenterol. 1996;15:46-8.

6. Fine KD, Stone MJ. Alpha-heavy chain disease, Mediterranean lymphoma, and immunoproliferative small intestinal disease: a review of clinicopathological features, pathogenesis, and differential diagnosis. Am J Gastroenterol. 1999;94:1139-52.

7. Fischbach W, Tacke W, Greiner A, Konrad H, Muller H. Regression of immunoproliferative small intestinal disease after eradication of Helicobacter pylori. Lancet. 1997;349:31-2.

8. Lecuit M, Abachin E, Martin A, Poyart C, Pochart P, Suarez F, et al. Immunoproliferative small intestinal disease associated with Campylobacter jejuni. N Engl J Med. 2004;350:239-48.

9. Al-Saleem T, Zardawi IM. Primary lymphomas of the small intestine in Iraq: a pathological study of 145 cases. Histopathology. 1979;3:89-106.

10. Nair S, Mathan M, Ramakrishna BS, Mathan VI. Immunoproliferative small intestinal disease in South India: a clinical and immunomorphological study. J Gastroenterol Hepatol. 1998;13:1207-11.

11. Salem P, Anaissie E, Allam C, Geha S, Hashimi L, Ibrahim N, et al. Non-Hodgkin's lymphomas in the Middle East. A study of 417 patients with emphasis on special features. Cancer. 1986;58:1162-6.

12. Al-Saleem T, Al-Mondhiry H. Immunoproliferative small intestinal disease (IPSID): a model for mature B-cell neoplasms. Blood. 2005;105:2274-80.

13. Rambaud JC, Halphen M, Galian A, Tsapis A. Immunoproliferative small intestinal disease (IPSID): relationships with alpha-chain disease and "Mediterranean" lymphomas. Springer Semin Immunopathol. 1990;12:239-50.

14. Yadav P, Das P, Mirdha BR, Gupta SD, Bhatnagar S, Pandey $\mathrm{RM}$, et al. Current spectrum of malabsorption syndrome in adults in India. Indian J Gastroenterol. 2011;30:22-8.

15. Ranjan P, Ghoshal UC, Aggarwal R, Pandey R, Misra A, Naik S, et al. Etiological spectrum of sporadic malabsorption syndrome in northern Indian adults at a tertiary hospital. Indian $J$ Gastroenterol. 2004;23:94-8.

16. Ghoshal UC, Mehrotra M, Kumar S, Ghoshal U, Krishnani N, Misra A, et al. Spectrum of malabsorption syndrome among adults $\&$ factors differentiating celiac disease \& tropical malabsorption. Indian J Med Res. 2012;136:451-9.

17. Salem PA, Estephan FF. Immunoproliferative small intestinal disease: current concepts. Cancer J. 2005;11:374-82.

18. Ben-Ayed F, Halphen M, Najjar T, Boussene H, Jaafoura H, Bouguerra A, et al. Treatment of alpha chain disease. Results of a prospective study in 21 Tunisian patients by the TunisianFrench intestinal Lymphoma Study Group. Cancer. 1989;63:1251-6.

19. Akbulut H, Soykan I, Yakaryilmaz F, Icii F, Aksoy F, Haznedaroglu S, et al. Five-year results of the treatment of 23 patients with immunoproliferative small intestinal disease: a Turkish experience. Cancer. 1997;80:8-14. 